\title{
Effectiveness of Digital Technology in Education During COVID-19 Pandemic. A Bibliometric Analysis
}

\author{
https://doi.org/10.3991/ijim.v15i08.20415 \\ Ishamuddin Mustapha $(\bowtie)$ \\ Universiti Kuala Lumpur, Kuala Lumpur, Malaysia \\ Ishamuddin@unikl \\ Nguyen Thuy Van \\ Universiti Teknologi Malaysia, Johor Bahru, Malaysia \\ Masoumeh Shahverdi \\ University of Stavanger, Stavanger, Norway \\ Muhammad Imran Qureshi \\ Universiti Teknikal Malaysia Melaka, Alor Gajah, Malaysia \\ Nohman Khan \\ Universiti Kuala Lumpur, Kuala Lumpur, Malaysia
}

\begin{abstract}
Digital technologies are viewing as a gateway to solve many of the problems arising from the crisis. How can we provide efficient education in COVID-19? To extend classroom learning to the home is a challenging task for the nations and the COVID-19 outbreak put the world in a situation from home learning. This study will analyze the overall resources and digital technologies available for education from home. For this purpose, Scopus and web of science databases are used to find the literature. The final 82 articles are select for the SLR (systematic literature review). The data inclusion and exclusion process are used in the PRISMA statement 2015 for quality assessment of data. The bibliometric analysis will conduct for text frequency co-occurrence and collaborations between the authors in countries. The vital step of data classification will process according to the author's segmentation and published research settings. In the last findings of the study, reports will explain past literature and recent outbreak. We are applying bibliometric analysis, showing that reviews are classified into 04 main clusters for analysis and discussion. These are 1) Digital Education Quick Shift Online Teaching and Learning for during Covid19 Pandemic 2) Digital Education during Pandemic and Rethinking for Sustainable Community; 3) Digital education for medical education and healthcare in hospital; 4) Digital Education and Digital innovation development during Covid19 pandemic. These findings are expected to benefit stakeholders studying and working relevant in digital education during and resilient post-Covid-19 pandemic.
\end{abstract}

Keywords-Digital Education, COVID-19, Digital Transformation, Digital Technologies 


\section{Introduction}

Digital technology is a primary medium of education in the COVID-19 outbreak for the institutions and students. In most of the world, the movement control order creates a challenging situation for the educational institutes to continue the face-toface classes to interact with the students [1]. Educational institutes are mostly dependent on the advancement of the Internet and digital networks to continue educational programs. For this purpose, countries with high internet infrastructure and devices can respond better to operate from the distance learning during the pandemic outbreak [2]. The outbreak not only challenges the economies and supply chain process of product manufacturing to delivery. However, the concept of digital distance learning is practically check in the COVID-19 outbreak. Many researchers believed that online learning and distance learning is possibly achievable with the current infrastructure. The pandemic outbreak proves that the resources and infrastructure available are not enough for digital education [3]. Digital transformation education is one of the hot debates for researchers in recent times after the pandemic outbreak. Researchers are conducting research related to the digital transformation of education, and many international forums are predicting the future of education is dependent on the digital transformation like the other fields of every day [4].

In this context, research areas have attracted a significant amount of interest in the digitalizing education field from the scientific and educational community-however, lack of paper review about the effectiveness of "digital education" during the Covid19 pandemic. Utilizing big database analysis to provide an adequate awareness of digitalizing education effects during the Covid19 pandemic, this paper selected papers related to Digital education for reviews by biometric analysis to explore emerging themes for explaining and discussion [5]. The structure of themes describes advances, challenges, and solutions that expect to produce a useful overview in resilient digital education post Covid19 pandemic.

\section{Materials and Methods}

In reporting the results and developing the research framework, authors worldwide are using the PRISMA statement 2015. The systematic literature review (SLR) is a guide to enhance the reviews and meta-analysis (Moher, Liberati, Tetzlaff, Altman, et al., 2009). The PRISMA statement template explains the overall research process to select and reject articles in this SLR. This SLR base study is limited to published literature on the topic of virtual reality and tourism. The two databases, the web of science and Scopus, are using for the literature extraction. Keywords are used Digital Education AND COVID-19 in the search bar, and the database's total results are 347. 


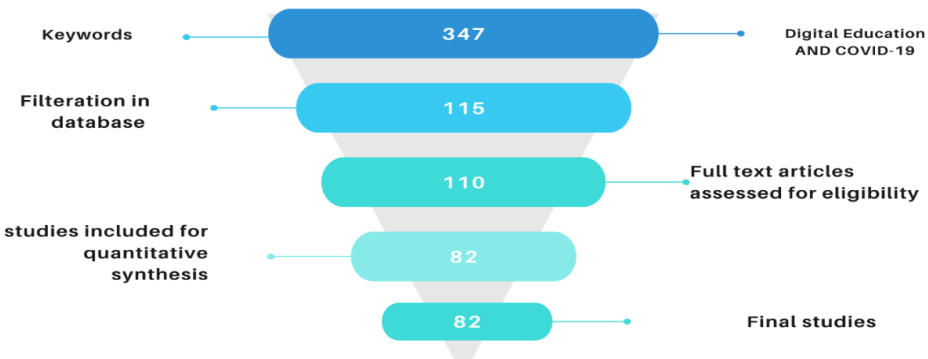

Fig. 1. PRISMA statement 2015

For the other process, subjects are selected for the current study, Social Sciences, Engineering, Environmental Sciences, Computer science, Mathematics, social science: Business, Management and Accounting, Environmental Science, Arts and Humanities, Economics, Econometrics, and finance, and multidisciplinary are selected. The results are narrow down to 234. Further on only articles, publishing stage final published paper, language English is chosen in the database. Results are narrowed down to 115 , and after removing the duplication, and irrelevant literature, the final 82 studies are included for the review. Figure 1 is showing the detailed process of data selection.

\section{$3 \quad$ Results}

\subsection{Descriptive analysis}

The study is focusing on education in the pandemic outbreak. The year-wise distribution's primary purpose is to understand the number of publications in a year selected and fulfil the review criteria. Figure 2 shows the year base graph of literature from 2020 and 2021. The year 2020 contributing the highest number with eighty. The year 2021 is second in the list, with two research papers on digital education in COVID-19.

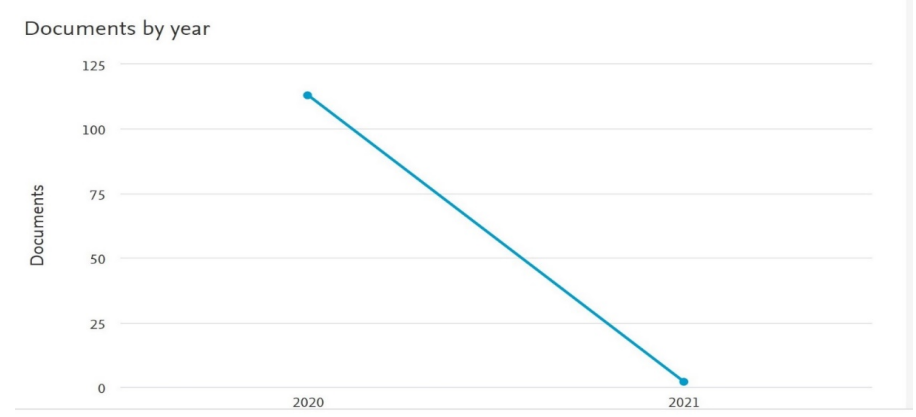

Fig. 2. Number of studies from each year 
The literature includes the outbreak of a pandemic, publications on COVID-19the United States' highest studies on digital education, and COVID-19 with 20 numbers. United Kingdom work about digitalization and education is very acknowledgeable as compare to the other countries. Canada, Australia, and Spain 7,4 and 4. Figure 2 is showing the number of articles from each country in detail.

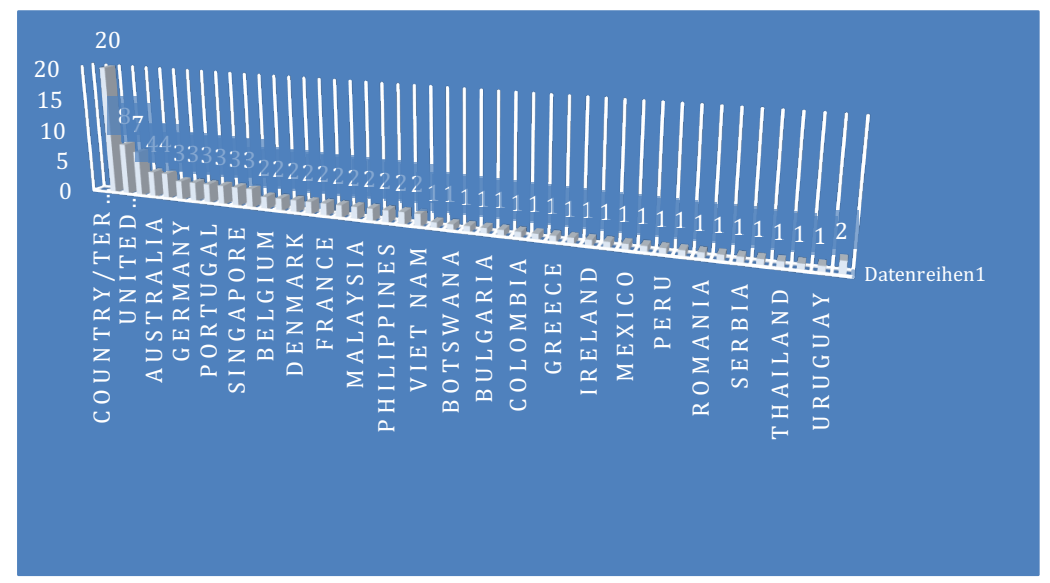

Fig. 3. Country base Publication

Furthermore, the journal base publication analysis is conducted for the current study and finds that the Journal of Chemical Education journal the ten publications. Second, most publications are select from Sustainability Switzerland with 7 in number. Gradually the name of the studies is going down for the current study. Information and Learning Science contributes to four articles. Figure 4 is showing the results of the research article selected from each journal.

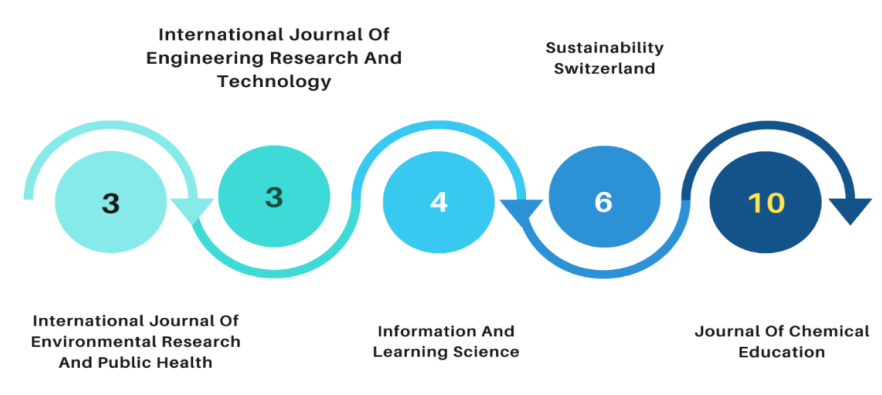

Fig. 4. Distribution of literature journal base publications 
Classification of literature and Bibliometrics: The following cluster of keywords inside figure 4 demonstrates either one that subject has been continuously discussed in the investigated articles over the entire considered time, and the keywords be an average of publication year, or that the issue was of interest and published in the journal in 2020 and 2021 when Covid19 pandemic occurred. Thus, part of this group are keywords such as 1) Classroom, early childhood education, secondary schools, high schools, higher education, pedagogy, significant difference, control group, 2) Education system, education process, requirements, industry, 3) Internet, security, database, employers, cost, delivery, 4) Intervention, digital health care, medical education, engineering education, which require continuous inquiries to reach common frameworks that provide an overall improvement of digital education in resilient post-Covid19. Figure 5 is showing the details of the clusters.

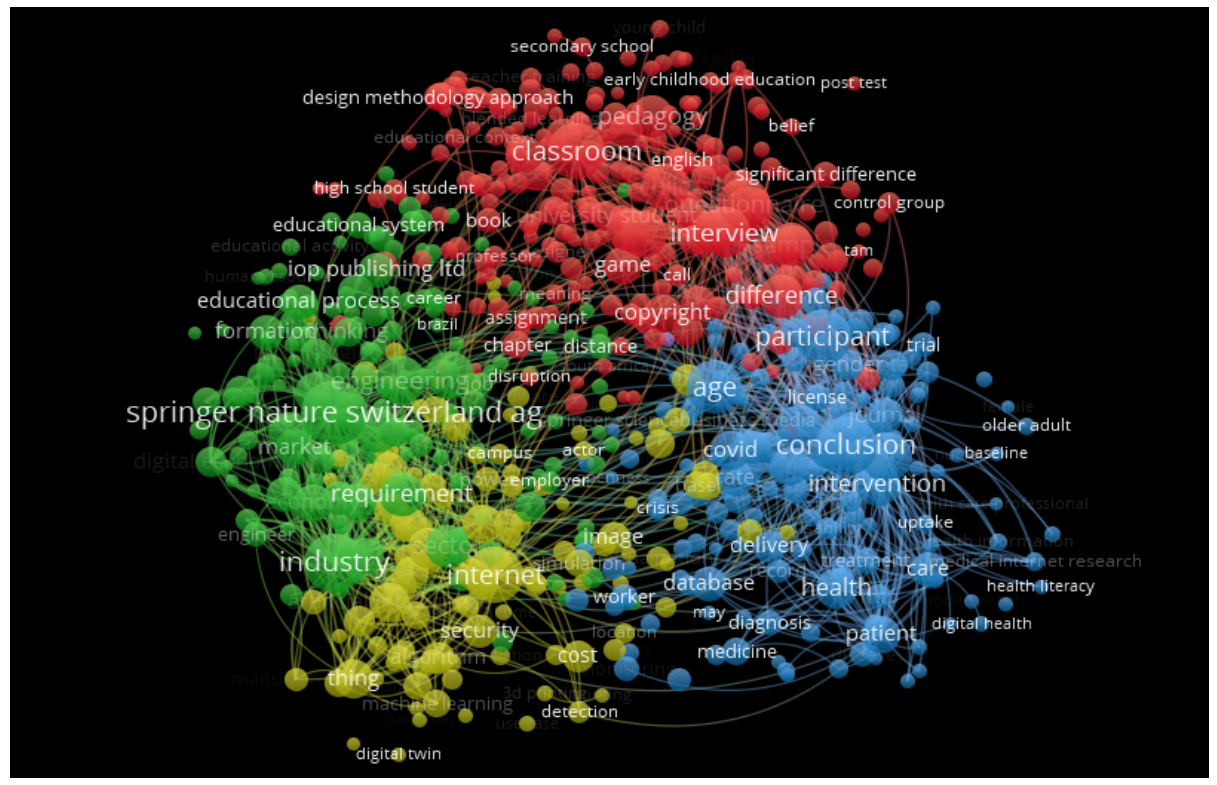

Fig. 5. Bibliometric analysis with keywords "digital education" with 2000 articles in Scopus database, accessed 12.2020.

\section{Classifying Effectiveness of Digital Education During COVID-19 Pandemic}

Based on database classification with a critical process to find actual work done on the topic, this study mainly sees an overview, detail, and comprehensive approach to finding literature about the effectiveness of digital technology in education during the Covid19 pandemic crisis. 


\subsection{Digital education quick shift online teaching and learning for during COVID-19 pandemic}

Although, digital education has increasing comprehensive of the enormous benefits of accessibility and outreach for teaching and learning, saving cost and time, flexible location, saving in terms of traveling, and make education more inclusive; however, only when Covid19 pandemic occurred in worldwide, digital education fully applied in educational system [6]. In Figure 6 review shows many researchers interested in digital education's effectiveness for online teaching and learning during the Covid-19 pandemic. First, digitally communicate platforms are useful tools for educational institutions survivors, and even winners, during the Covid19 crisis [7]. Digital education has provided a platform for teaching and learning to be able to continue for student's achievements [6]; Digital education has practiced in all levels of the education system, from preschool to higher education, during a pandemic and has been predicted to continue applied to resilient post-COVID-19 by strength benefits for stakeholder's satisfy. The posts or conversation (text/image/poster) and videos one way and multi ways together virtual meeting discussing these all-educational institutions or schools share are more concentrated on either press agentry or the public information model. Digital communication using in guidance, inform, support staff and students moving on the face-to-face class to online class successfully, through digital platforms, asynchronous or synchronous; virtual experiment videos also a tool to support students in this case for learning achievement [8]. These studies believed that integrating learning theories with technology has changed students' thinking and ways of constructing knowledge and, based on this, learning achievement building, and keeping students grow up. Several studies mentioned online learning methodologies for engaging and supporting students' learning satisfaction and learning achievement [9].

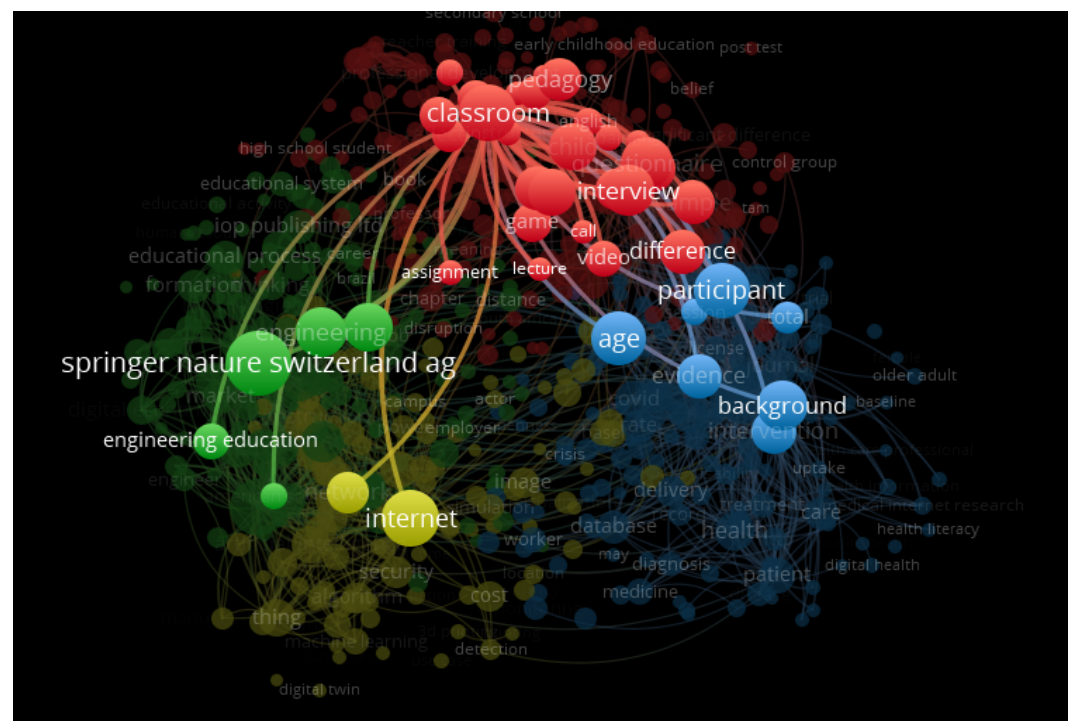

Fig. 6. Education" (Scopus database, accessed 12.2020) 
Another benefit is that digital education is applied to ensure students in their final year can continue with their education and graduation as anticipated when they must stay at home by the coronavirus. That provides a significant number of high skill labour resources for the labour market, especially digital jobs, and contributes to keeping the national economic development worldwide [10]. Computer communication skills refer to reviews for students studying achievement and career development also discussed [10]. Besides teaching and learning, digital education connects scholars in the world with several attractive studies. With the context of national border closed and traveling crossing countries limited, the evolution of digital education opens a new platform for global exchange and sharing knowledge, virtual international conferences implementing in many universities in different countries and create ample space for staff and students sharing and discuss; global class occurred $\mathrm{n}$ several places in the world [11], [12].

Besides the advantages of digital technology for education during the Covid-19 pandemic, remote education reviews indicated some challenges. Teachers challenge in readiness using technologies to connect with students and online teaching pedagogy when full online teaching and learning applying during Covid19 pandemic [13]. Students' learning performance from online learning assessment shows challenges, especially medical education ([14], [15], [16]. Some subjects related to physical skills development facing many struggles, like sports education, medical practice, became difficult facing [16][17]. Some universities have not succeeded in student achievement in the early semester pandemic, such as nearly half reported lowering the expected volume of work for students (including dropping assignments or exams) and shifting to a pass/fail model of online learning [10], [18].

This teacher education force is innovative training to adapt to digitalizing education in the future [19]. Solutions for improving learning achievements through distance education also discussing, such as universities should restructure curriculums and outcomes as well as provide good enough facility for technical equipment wellrunning [5] [20], teachers and students invest enough time, training, and practice for readiness as well as critical digital pedagogy [21]; [10]; [22]; student engagement, involved and participate in online learning activities is critical for success in online courses [23],[24] devising and maintaining an encouraging learning atmosphere, giving students consistent and prompt feedback, using a variety of technologies, building community [20].

Table 1. Author, title, advances, challenges, and solution recommendation

\begin{tabular}{|l|l|l|l|l|l|}
\hline No & \multicolumn{1}{|c|}{ Authors } & \multicolumn{1}{|c|}{ Title } & \multicolumn{1}{c|}{ Advances } & \multicolumn{1}{c|}{ Challenges } & \multicolumn{1}{c|}{ Solutions } \\
\hline 1 & $\begin{array}{l}\text { Daniel } \\
{[6]}\end{array}$ & $\begin{array}{l}\text { Education and the } \\
\text { COVID-19 pan- } \\
\text { demic }\end{array}$ & $\begin{array}{l}\text { Address issue of students } \\
\text { continues to study when } \\
\text { staying at home \& giving } \\
\text { Viewpoint. }\end{array}$ & $\begin{array}{l}\text { Constructing cur- } \\
\text { ricula, designing } \\
\text { student assessment }\end{array}$ & $\begin{array}{l}\text { Advantages of } \\
\text { asynchronous } \\
\text { learning. }\end{array}$ \\
\hline 2 & $\begin{array}{l}\text { Khalil et. al. } \\
{[5]}\end{array}$ & $\begin{array}{l}\text { The effectiveness } \\
\text { of synchronized } \\
\text { online learning } \\
\text { (1) Educational impact, } \\
\text { (2) Time management, } \\
\text { (3) Challenges encoun- } \\
\text { tered, and (4) Preferences } \\
\text { for the future. }\end{array}$ & $\begin{array}{l}\text { lethodological, } \\
\text { tontent perception, } \\
\text { behnical, and } \\
\text { behavioural chal- } \\
\text { lenges during } \\
\text { sessions and online }\end{array}$ & $\begin{array}{l}\text { Online learning } \\
\text { model and learning } \\
\text { outcomes should be } \\
\text { rigorously and } \\
\text { regularly evaluated } \\
\text { to monitor its }\end{array}$ \\
\hline
\end{tabular}




\begin{tabular}{|c|c|c|c|c|c|}
\hline & & & & exams & effectiveness \\
\hline 3 & $\begin{array}{l}\text { Sá \& Serpa, } \\
{[20]}\end{array}$ & $\begin{array}{l}\text { COVID-19 and the } \\
\text { promotion of } \\
\text { digital competenc- } \\
\text { es in education }\end{array}$ & $\begin{array}{l}\text { Reformulation of educa- } \\
\text { tion shaped by the digital } \\
\text { platform. }\end{array}$ & $\begin{array}{l}\text { Teaching pedagogy } \\
\& \text { Learning styles }\end{array}$ & $\begin{array}{l}\text { Reformulating } \\
\text { teachers and stu- } \\
\text { dents of digital } \\
\text { technologies in } \\
\text { shaping digital } \\
\text { society. }\end{array}$ \\
\hline 4 & $\begin{array}{l}\text { Ayman, } \\
\text { Kaya \& } \\
\text { Kuruç, [17] }\end{array}$ & $\begin{array}{l}\text { The impact of } \\
\text { digital communi- } \\
\text { cation and pr } \\
\text { models on the } \\
\text { sustainability of } \\
\text { higher education } \\
\text { during crises } \dagger\end{array}$ & $\begin{array}{l}\text { maintained sustainability } \\
\text { in higher education } \\
\text { during COVID-19 by } \\
\text { discussing the public } \\
\text { relations models. }\end{array}$ & $\begin{array}{l}\text { Quality of the } \\
\text { Internet } \\
\text { how they handle } \\
\text { crisis communica- } \\
\text { tion. }\end{array}$ & $\begin{array}{l}\text { Digital communica- } \\
\text { tion } \\
\text { popularly applying } \\
\text { in the universities }\end{array}$ \\
\hline 5 & $\begin{array}{l}\text { Hall et } \\
\text { al.[12] }\end{array}$ & \begin{tabular}{|l|} 
Education in \\
precarious times: a \\
comparative study \\
across six coun- \\
tries to identify \\
design priorities \\
for mobile learning \\
in a pandemic \\
\end{tabular} & $\begin{array}{l}\text { Designing and Evaluating } \\
\text { Innovative Mobile Peda- } \\
\text { gogies" (DEIMP). }\end{array}$ & $\begin{array}{l}\text { Innovative mobile } \\
\text { pedagogies }\end{array}$ & $\begin{array}{l}\text { Provide pragmatic } \\
\text { guidelines in remote } \\
\text { education } \\
\text { innovative mobile } \\
\text { pedagogies }\end{array}$ \\
\hline 6 & $\begin{array}{l}\text { Kim S., } \\
\text { Rosenblith } \\
\text { S., Chang Y., } \\
\text { Pollack S. } \\
{[18]}\end{array}$ & $\begin{array}{l}\text { Will it access and } \\
\text { use support URM } \\
\text { students' online } \\
\text { learning in the } \\
\text { (Post) covid-19 } \\
\text { era? }\end{array}$ & $\begin{array}{l}\text { Explored how infor- } \\
\text { mation and communica- } \\
\text { tions and media technol- } \\
\text { ogy (ICMT) access and } \\
\text { uses for learning have } \\
\text { influenced students' }\end{array}$ & & \\
\hline 7 & $\begin{array}{l}\text { Firmansyah, } \\
\text { MOH TINO } \\
{[7]}\end{array}$ & $\begin{array}{l}\text { Using big and } \\
\text { open data to gen- } \\
\text { erate content for an } \\
\text { educational game } \\
\text { to increase student } \\
\text { performance and } \\
\text { interest }\end{array}$ & $\begin{array}{l}\text { Utilizing available big } \\
\text { and open data sets to } \\
\text { create content for a board } \\
\text { and a digital game and } \\
\text { implement an educational }\end{array}$ & $\begin{array}{l}\text { Academic perfor- } \\
\text { mance and engage- } \\
\text { ment. }\end{array}$ & $\begin{array}{l}\text { Provide an envi- } \\
\text { ronment to improve } \\
\text { students' familiarity } \\
\text { with concepts and } \\
\text { relations in the data. }\end{array}$ \\
\hline 8 & $\begin{array}{l}\text { Shenoy, } \\
\text { Veena } \\
\text { Mahendra, } \\
\text { Sheetal } \\
\text { Vijay, Navita } \\
{[23]}\end{array}$ & $\begin{array}{l}\text { University stu- } \\
\text { dents' readiness } \\
\text { for using digital } \\
\text { media and online } \\
\text { learning- } \\
\text { Comparison be- } \\
\text { tween Germany } \\
\text { and the USA }\end{array}$ & $\begin{array}{l}\text { Evaluated of German } \\
\text { university students' } \\
\text { readiness for using digital } \\
\text { media and online com- } \\
\text { pared with students from } \\
\text { the United States. }\end{array}$ & $\begin{array}{l}\text { Students being more } \\
\text { ready for online } \\
\text { learning. }\end{array}$ & \\
\hline 9 & Iivari [8] & \begin{tabular}{|l|} 
Empowering \\
children to make \\
and shape our \\
digital futures - \\
from adults creat- \\
ing technologies to \\
children transform- \\
ing cultures \\
\end{tabular} & $\begin{array}{l}\text { Children's education in } \\
\text { the digital age in general }\end{array}$ & $\begin{array}{l}\text { Teachers and facili- } \\
\text { tators are working } \\
\text { in practicing in } \\
\text { digital education }\end{array}$ & $\begin{array}{l}\text { Children should be } \\
\text { empowered to } \\
\text { engage in making } \\
\text { and shaping our } \\
\text { digital futures. }\end{array}$ \\
\hline 10 & $\begin{array}{l}\text { Johnson N., } \\
\text { Veletsianos } \\
\text { G., Seaman J. } \\
{[10]}\end{array}$ & $\begin{array}{l}\text { US faculty and } \\
\text { administrators' } \\
\text { experiences and } \\
\text { approaches in the } \\
\text { early weeks of the } \\
\text { COVID-19 pan- }\end{array}$ & $\begin{array}{l}\text { The rapid transition to } \\
\text { emergency remote teach- } \\
\text { ing in the early weeks }\end{array}$ & $\begin{array}{l}\text { Nearly half reported } \\
\text { lowering the ex- } \\
\text { pected volume of } \\
\text { work for students } \\
\text { (including dropping } \\
\text { assignments or }\end{array}$ & $\begin{array}{l}\text { The primary areas } \\
\text { where faculty and } \\
\text { administrators } \\
\text { identified a need for } \\
\text { assistance related to } \\
\text { student support, }\end{array}$ \\
\hline
\end{tabular}




\begin{tabular}{|c|c|c|c|c|c|}
\hline & & demic & & $\begin{array}{l}\text { exams) and shifting } \\
\text { to a pass/fail model } \\
\text { for this semester. }\end{array}$ & \begin{tabular}{|l|} 
greater access to \\
online digital mate- \\
rials, and guidance \\
for working from \\
home. \\
\end{tabular} \\
\hline 11 & $\begin{array}{l}\text { Song, Joon- } \\
\text { Young } \\
\text { Yun, Jin-Gu } \\
\text { Noh, Ji-Yun } \\
\text { Cheong, } \\
\text { Hee-Jin } \\
\text { Kim, Woo- } \\
\text { Joo [15] }\end{array}$ & $\begin{array}{l}\text { Perceived usability } \\
\text { evaluation of } \\
\text { Microsoft Teams } \\
\text { as an online learn- } \\
\text { ing platform } \\
\text { during COVID-19 } \\
\text { using system } \\
\text { usability scale and } \\
\text { technology ac- } \\
\text { ceptance model in } \\
\text { India }\end{array}$ & $\begin{array}{l}\text { Digital-divide aspect } \\
\text { (mobile vs. web envi- } \\
\text { ronment) prevalent, } \\
\text { particularly in developing } \\
\text { countries }\end{array}$ & $\begin{array}{l}\text { Student perfor- } \\
\text { mance } \\
\text { the game impacted } \\
\text { the students' per- } \\
\text { formance, across } \\
\text { genders. }\end{array}$ & $\begin{array}{l}\text { the positive correla- } \\
\text { tion between stu- } \\
\text { dent interest and } \\
\text { performance illus- } \\
\text { trated the relation- } \\
\text { ship between them. }\end{array}$ \\
\hline 12 & $\begin{array}{l}\text { Kim C.J.H., } \\
\text { Padilla A.M. } \\
{[18]}\end{array}$ & \begin{tabular}{|l|} 
Technology for \\
Educational Pur- \\
poses Among \\
Low-Income \\
Latino Children \\
Living in a Mobile \\
Park in Silicon \\
Valley: A Case \\
Study Before and \\
During COVID-19
\end{tabular} & $\begin{array}{l}\text { Significant barriers to } \\
\text { having adequate access to } \\
\text { technology at home due } \\
\text { to socioeconomic barri- } \\
\text { ers. }\end{array}$ & & \begin{tabular}{|l|} 
Systematic im- \\
provement are \\
required in order to \\
eliminate disparities \\
and improve student \\
learning and paren- \\
tal involvement \\
with schooling for \\
marginalized com- \\
munities
\end{tabular} \\
\hline 13 & $\begin{array}{l}\text { Khan, M.I } \\
\text { Qureshi [5] }\end{array}$ & $\begin{array}{l}\text { University stu- } \\
\text { dents' readiness } \\
\text { for using digital } \\
\text { media and online } \\
\text { learning- } \\
\text { Comparison be- } \\
\text { tween Germany } \\
\text { and the USA }\end{array}$ & $\begin{array}{l}\text { Universities needed to } \\
\text { change their teaching } \\
\text { practices due to the } \\
\text { COVID-19 pandemic by } \\
\text { digital education. }\end{array}$ & $\begin{array}{l}\text { Technical infra- } \\
\text { structure everybody } \\
\text { is also ready to use } \\
\text { it. Thus, the present } \\
\text { study focused on } \\
\text { the issue }\end{array}$ & $\begin{array}{l}\text { Of university stu- } \\
\text { dents' readiness for } \\
\text { online learning. }\end{array}$ \\
\hline 14 & $\begin{array}{l}\text { Sá M.J., } \\
\text { Serpa S. [9] }\end{array}$ & \begin{tabular}{|l|} 
The covid-19 \\
pandemic as an \\
opportunity to \\
foster the sustaina- \\
ble development of \\
teaching in higher \\
education
\end{tabular} & Roles of Leadership & & $\begin{array}{l}\text { Digital education } \\
\text { culture }\end{array}$ \\
\hline 15 & $\begin{array}{l}\text { Fujita N } \\
{[22]}\end{array}$ & \begin{tabular}{|l|} 
Transforming \\
online teaching \\
and learning: \\
towards learning \\
design informed by \\
information sci- \\
ence and learning \\
sciences
\end{tabular} & $\begin{array}{l}\text { Provide an overview of } \\
\text { the information science } \\
\text { (IS) and learning sciences } \\
\text { (LS) in designing of } \\
\text { online teaching and } \\
\text { online learning in higher. }\end{array}$ & $\begin{array}{l}\text { Highlighting the } \\
\text { role that infor- } \\
\text { mation systems and } \\
\text { computer-human } \\
\text { interaction. }\end{array}$ & $\begin{array}{l}\text { The combined } \\
\text { considers issues of } \\
\text { social justice and } \\
\text { equity and critical } \\
\text { digital pedagogy. }\end{array}$ \\
\hline 16 & $\begin{array}{l}\text { Toquero, } \\
\text { Cathy Mae } \\
{[13]}\end{array}$ & $\begin{array}{l}\text { Self-regulated } \\
\text { learning in online } \\
\text { learning environ- } \\
\text { ments: strategies } \\
\text { for remote learning }\end{array}$ & $\begin{array}{l}\text { Identify and describe the } \\
\text { self-regulated learning } \\
\text { (SRL) framework in } \\
\text { online environments }\end{array}$ & $\begin{array}{l}\text { Considering how } \\
\text { student learn during } \\
\text { online environment, } \\
\text { the need of support, } \\
\text { monitoring en- } \\
\text { gagement, and } \\
\text { supporting families. }\end{array}$ & $\begin{array}{l}\text { Although the social } \\
\text { crisis of COVID-19 } \\
\text { is unique, prior } \\
\text { research in online } \\
\text { learning may sup- } \\
\text { port teacher practice } \\
\text { and suggest future } \\
\text { research. }\end{array}$ \\
\hline
\end{tabular}




\subsection{Digital education during pandemic and rethinking for sustainable community}

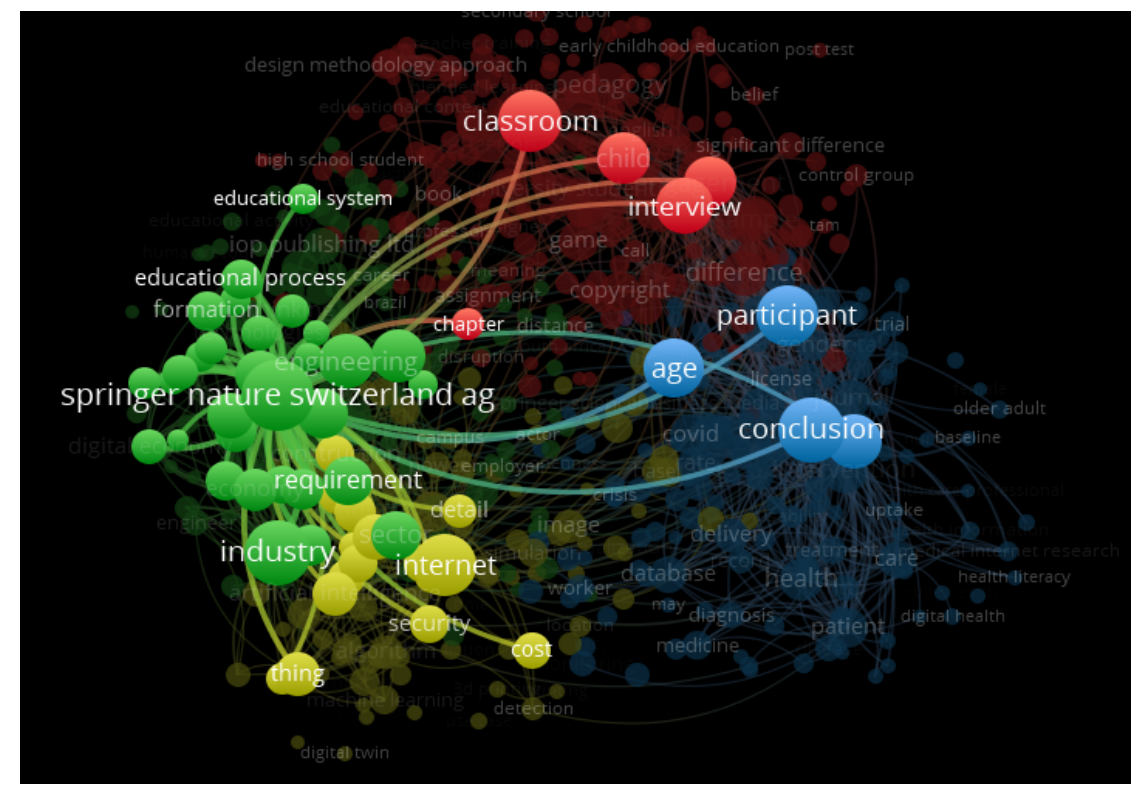

Fig. 7. Bibliometric analysis with a cluster of "sustainable community development" among data of "digital education" (Scopus database, accessed 12.2020)

When children must stay at home and parents must work from home during lockdown time by COVID-19 pandemic, schools closed, digital education show advances to provide a platform for students continue to be educated by online learning. More than millions of children worldwide, have been continued learning at home to enhance experiences and constructive knowledge for sustainable community development [25]. The pandemic has shown how communities can educate children; parents are the teachers to support children at home or learn from each other through a digital platform [26]. Digital education has not only to support children learning, it significantly impacted the human capital labor market for training, sharing knowledge and experience related multi-fields for eco-social community development, such as online business, online transportation, especially in low-income areas or villages and most women quickly learn how to use online business from a digital technology for enhancing knowledge to self- healthcare protect and maintaining the life at home when they could not go out [27]; When national borders closed, public transportation stopped, entertainment $\&$ restaurants service in temporary no working, many workers dropped in status out of work [28]. In developing countries, people need to quickly learn new knowledge \& skills to find any legal jobs. Digital technology is the best choice when the digital economy opens new jobs in workplaces. By this way, community people started to learn and finding job, for example, drivers and customers learning how to use the app for transportation; workers in factories learn how to man- 
age their job when they work at home; restaurant opens online service and brings food to home during lockdown time. Digital education contributed to enhancing digital competence for community workforce people to adapt to the new digital working environment during a pandemic [29]. Another benefit of digital education is the psychological and psychiatric disorders in some people and creates peace \& safety when a pandemic crisis negatively impacts the community during a pandemic [30]. Figure 7 shows the Bibliometric analysis with a cluster of "sustainable community development" among data of "digital education."

However, challenges of sustainable development based on digital education are in review with many issues. Internet facility in the community becomes the enviable factor for people to communicate together during lockdown time [31]. Pandemic let community authorities rethinking school functions and re-imagine and re-design education for the future [25]; Before the pandemic, knowledge is mainly transferred to students from teachers in schools. However, during a pandemic, digital education opens a blended learning environment for education, even if they are assisted by TVs, smartphones, feature phones, laptops, and tablets. Google Classroom has developed a whole suite of integrated learning platforms that can be easily linked to YouTube, Lexia, Khan Academy, and other teaching aids. Community members use digital tools to created virtual storytelling sessions contribute knowledge sharing for sustainable development [25],[32]. Some researchers discussed the financial resources and finance management for children living in low-income families to get enough digital tools, and equality chances in education have been discussed. Such as Iyengar R. [25] post-COVID-19, education systems should recognize community-driven support systems, use technology to overcome the digital divide in learning, bring equality of education for all children in the world [33], [27].

Table 2. Digital Education during Pandemic and Rethinking for Sustainable Community

\begin{tabular}{|c|c|c|c|c|c|}
\hline No & Authors & Title & Advances & Challenges & Solutions \\
\hline 1. & Iyengar R. [25] & $\begin{array}{l}\text { Education as the } \\
\text { path to a sustain- } \\
\text { able recovery } \\
\text { from COVID-19 }\end{array}$ & $\begin{array}{l}\text { The pandemic has } \\
\text { shown how communi- } \\
\text { ties can come together } \\
\text { to educate children and } \\
\text { develop economic by } \\
\text { digital education. }\end{array}$ & $\begin{array}{l}\text { Futures Education } \\
\text { initiative to high- } \\
\text { light importance } \\
\text { in post-COVID-19 } \\
\text { recovery. }\end{array}$ & \begin{tabular}{|l|} 
Post-COVID-19, \\
education systems \\
should recognize \\
community-driven \\
support systems with \\
digital technology.
\end{tabular} \\
\hline 2. & $\begin{array}{l}\text { Dwivedi Y.K., } \\
\text { Hughes D.L., } \\
\text { Coombs C., Con- } \\
\text { stantinou I., Duan } \\
\text { Y., Edwards J.S., } \\
\text { Gupta B., Lal B., } \\
\text { Misra S., Prashant } \\
\text { P., Raman R., } \\
\text { Rana N.P., Sharma } \\
\text { S.K., Upadhyay N. } \\
{[26]}\end{array}$ & $\begin{array}{l}\text { Impact of } \\
\text { COVID-19 } \\
\text { pandemic on } \\
\text { information } \\
\text { management } \\
\text { research and } \\
\text { practice: Trans- } \\
\text { forming educa- } \\
\text { tion, work, and } \\
\text { life }\end{array}$ & $\begin{array}{l}\text { Undergo significant } \\
\text { transformation, rethink- } \\
\text { ing key elements of } \\
\text { their business processes } \\
\text { and using technology to } \\
\text { maintain operations } \\
\text { while adhering to a } \\
\text { changing landscape of } \\
\text { guidelines and new } \\
\text { procedures. }\end{array}$ & \begin{tabular}{|l|} 
Online learning, \\
digital strategy, \\
artificial intelli- \\
gence, infor- \\
mation manage- \\
ment, social \\
interaction, cyber, \\
security, big data, \\
blockchain, priva- \\
cy, mobile tech- \\
nology, and \\
strategy
\end{tabular} & $\begin{array}{l}\text { The expert perspec- } \\
\text { tives offer timely } \\
\text { insight into the } \\
\text { range of topics, } \\
\text { identifying key } \\
\text { issues and recom- } \\
\text { mendations for } \\
\text { theory and practice. }\end{array}$ \\
\hline 3. & $\begin{array}{l}\text { Iivari N., Sharma } \\
\text { S., Ventä- } \\
\text { Olkkonen L. }\end{array}$ & $\begin{array}{l}\text { Digital transfor- } \\
\text { mation of every- } \\
\text { day life - How }\end{array}$ & $\begin{array}{l}\text { Digital transformation } \\
\text { initiated in the basic } \\
\text { education equipping }\end{array}$ & \begin{tabular}{|l|} 
Today's children \\
are not equally \\
equipped for their
\end{tabular} & $\begin{array}{l}\text { Information man- } \\
\text { agement research } \\
\text { should better }\end{array}$ \\
\hline
\end{tabular}




\begin{tabular}{|c|c|c|c|c|c|}
\hline & {$[27]$} & \begin{tabular}{|l|} 
the COVID-19 \\
pandemic trans- \\
formed the \\
young genera- \\
tion's basic \\
education and \\
why information \\
management \\
research should \\
care?
\end{tabular} & $\begin{array}{l}\text { them with important } \\
\text { skills, career option and } \\
\text { competencies for their } \\
\text { digital futures. }\end{array}$ & \begin{tabular}{|l|} 
technology-rich \\
future: various \\
kinds of digital \\
divides still pre- \\
vail in society and \\
affect the young \\
generation and \\
their digital fu- \\
tures.
\end{tabular} & $\begin{array}{l}\text { acknowledge chil- } \\
\text { dren, their digital- } \\
\text { ized everyday life, } \\
\text { and their basic } \\
\text { education as signifi- } \\
\text { cant areas of con- } \\
\text { cern to be able to } \\
\text { meet the needs of } \\
\text { the young generation } \\
\text { and their digitalized } \\
\text { future }\end{array}$ \\
\hline 4. & $\begin{array}{l}\text { Choi, Jieun } \\
\text { Dutz, Mark } \\
\text { Usman, Zainab } \\
{[28]}\end{array}$ & \begin{tabular}{|l|} 
Exploring a Post- \\
COVID-19 \\
Sustainable \\
Peace Model
\end{tabular} & $\begin{array}{l}\text { The model is catego- } \\
\text { rized into four aspects: } \\
\text { promotion of human } \\
\text { security; achieving } \\
\text { social justice; honing } \\
\text { the capacity to hold } \\
\text { multiple perspectives } \\
\text { and patterns of thought } \\
\text { without relying on any } \\
\text { fixed position. }\end{array}$ & $\begin{array}{l}\text { A comprehensive } \\
\text { peace model for } \\
\text { individuals is } \\
\text { examined. }\end{array}$ & \begin{tabular}{|l|} 
Empowerment of \\
individual citizens \\
with four aspects of \\
peace will lead to \\
changing the course \\
of current global \\
politics based on \\
confrontational \\
relationships into \\
mutually contributo- \\
ry and creative \\
processes
\end{tabular} \\
\hline 5. & $\begin{array}{l}\text { Abideen, Ahmed } \\
\text { Zainul } \\
\text { Mohamad, Faz- } \\
\text { eeda Binti } \\
\text { Hassan, Mohd } \\
\text { Rohaizat } \\
\text { [31] }\end{array}$ & \begin{tabular}{|l|} 
From fighting \\
COVID-19 \\
pandemic to \\
tackling sustain- \\
able development \\
goals: An oppor- \\
tunity for respon- \\
sible information \\
systems research
\end{tabular} & $\begin{array}{l}\text { The coronavirus pan- } \\
\text { demic in dangerous and } \\
\text { also presents an excel- } \\
\text { lent opportunity for the } \\
\text { human family to act in } \\
\text { solidarity and turn this } \\
\text { crisis into an impetus to } \\
\text { achieve Sustainable } \\
\text { Development Goals } \\
\text { (SDG). }\end{array}$ & $\begin{array}{l}\text { Call for more } \\
\text { research attention } \\
\text { on tackling SDG } \\
\text { through develop- } \\
\text { ing the concept } \\
\text { and practice of } \\
\text { digital sustainabil- } \\
\text { ity. }\end{array}$ & $\begin{array}{l}\text { "The new normal," } \\
\text { it makes sense to } \\
\text { reflect on what we } \\
\text { have learned, revisit } \\
\text { our fundamental } \\
\text { assumptions, and } \\
\text { start charting the } \\
\text { way forward to } \\
\text { contribute to build- } \\
\text { ing a sustainable } \\
\text { world. }\end{array}$ \\
\hline 6. & $\begin{array}{l}\text { Oberländer, Maren } \\
\text { Beinicke, Andrea } \\
\text { Bipp, Tanja } \\
{[29]}\end{array}$ & $\begin{array}{l}\text { Transferring } \\
\text { COVID-19 } \\
\text { challenges into } \\
\text { learning poten- } \\
\text { tials: Online } \\
\text { workshops in } \\
\text { architectural } \\
\text { education }\end{array}$ & $\begin{array}{l}\text { Architectural education } \\
\text { regarding the need to } \\
\text { develop new teaching } \\
\text { methodology approach- } \\
\text { es, improve curricula, } \\
\text { and make advancements } \\
\text { in new learning arenas } \\
\text { and digital environ- } \\
\text { ments. }\end{array}$ & \begin{tabular}{|l|} 
To COVID-19 \\
challenges regard- \\
ing social distanc- \\
ing, limited \\
movements, \\
regulated use of \\
public space, and \\
suspended daily \\
activities. \\
learning limitation
\end{tabular} & $\begin{array}{l}\text { Four main COVID- } \\
19 \text { design challenges } \\
\text { perceived in perfor- } \\
\text { mance, innovation, } \\
\text { alteration, and } \\
\text { inclusion. }\end{array}$ \\
\hline 7. & $\begin{array}{l}\text { Gómez-Galán J., } \\
\text { Martínez-López } \\
\text { J.A., Lázaro-Pérez } \\
\text { C., Sánchez- } \\
\text { Serrano J.L.S. } \\
\text { [30] }\end{array}$ & $\begin{array}{l}\text { Social networks } \\
\text { consumption and } \\
\text { addiction in } \\
\text { college students } \\
\text { during the } \\
\text { COVID-19 } \\
\text { pandemic: Edu- } \\
\text { cational approach } \\
\text { to the responsible } \\
\text { use }\end{array}$ & $\begin{array}{l}\text { The increase in Internet } \\
\text { consumption and online } \\
\text { social networks offers } \\
\text { social benefits within } \\
\text { the digital sustainability } \\
\text { framework but is not } \\
\text { without its drawbacks. }\end{array}$ & $\begin{array}{l}\text { University stu- } \\
\text { dents are heavy } \\
\text { users of the Inter- } \\
\text { net, online social } \\
\text { networks; this can } \\
\text { result from de- } \\
\text { pression, harass- } \\
\text { ment, and anxiety, } \\
\text { and negative } \\
\text { affecting their } \\
\text { daily life, includ- } \\
\text { ing their academic } \\
\text { responsibilities. }\end{array}$ & $\begin{array}{l}\text { An educational } \\
\text { program to redirect } \\
\text { these addictive } \\
\text { behaviours and } \\
\text { preventative rec- } \\
\text { ommendations and } \\
\text { actions to minimize } \\
\text { negative impacts. }\end{array}$ \\
\hline
\end{tabular}




\subsection{Digital education for medical education and healthcare in hospital}

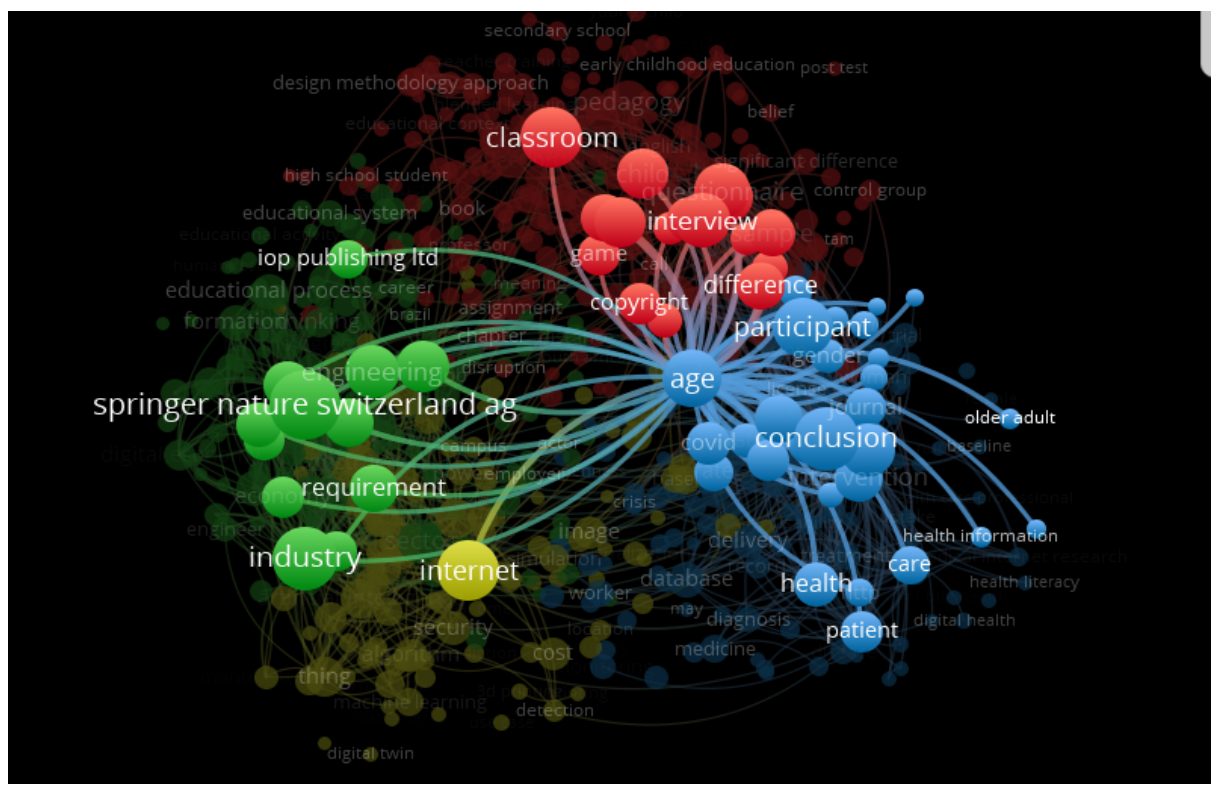

Fig. 8. Bibliometric analysis with a cluster of "medical education" among data of "digital education" (Scopus database, accessed 12.2020)

Digital education has a significant impact directly on medical education during the Covid19 pandemic. The pandemic has resulted in the widespread disruption of medical education and professional training; examples include reduced teaching with the redeployment of medical educators to clinical care and the quarantine and impact of illness on medical educators and students [34]. The reason is when a huge number of professors, doctors, nurse, students who involve with activities for treatment of patients in the hospital and suddenly facing the number of death increased by a coronavirus, especially this virus outbreak in the world and became the serious risks to staff and students practice in hospitals [35]. Medical education has experienced major troublesome changes as a significant impact of the Covid19 pandemic, and digital education has been rapidly applied innovatively to maintain teaching and learning in a difficult situation [36]. Figure 8 shows Bibliometric analysis with a cluster of "medical education" among data of "digital education." These encounters range from the clinic and ward rounds to interactive patient sessions to training in interpersonal and interprofessional communication and clinical skills that programs need to change and support digital education [37]. Instead of this, currently available technology, such as videos, podcasts, simple virtual reality, computer simulations, and serious games, is beginning to assist educators and facilitate student learning and training in these areas [36]. Medical educators can remotely coach students with real-time mobile video tools and apps. Simple online platforms, such as websites and blogs, can provide basic information and offer opportunities to host videos to demonstrate essential skills, such 
as procedural clinical skills and communication [38]. The use of emergent technology for education, such as artificial intelligence for adaptive learning and virtual reality, are highly likely to be essential components of the transformative change and the future of medical education [39]. These changes across the continuum of medical education have been mainly to replace existing approaches for providing medical education, driven by the urgency to implement a feasible and practical solution to the crises, with educators using standard technology. Overall, the pandemic's current response has been the increased awareness and adoption of currently available technologies in medical education and the wider education sector [40].

\subsection{Digital education and digital innovation development during COVID-19 pandemic}

Education correlates significantly with innovation and mainly responds to contributing to social-economic development. Digital innovation provides flatform for digital education in teaching and learning and transition information and knowledge to the community during a pandemic [41]. No doubt, digital education is the best environment for professors, teachers, and students to produce innovative ideas and products for digital innovation development. Based on reviews of more than 1500 articles related to digital innovation during the pandemic in Scopus database access on December 2020; the rate of subjects component shows remarkable numbers for social sciences, business management, computer sciences, engineering, medicine $(20.3 \%$; $16.7 \% ; 12.2 \% ; 9.8 \% ; 8.1 \%$ respectively).

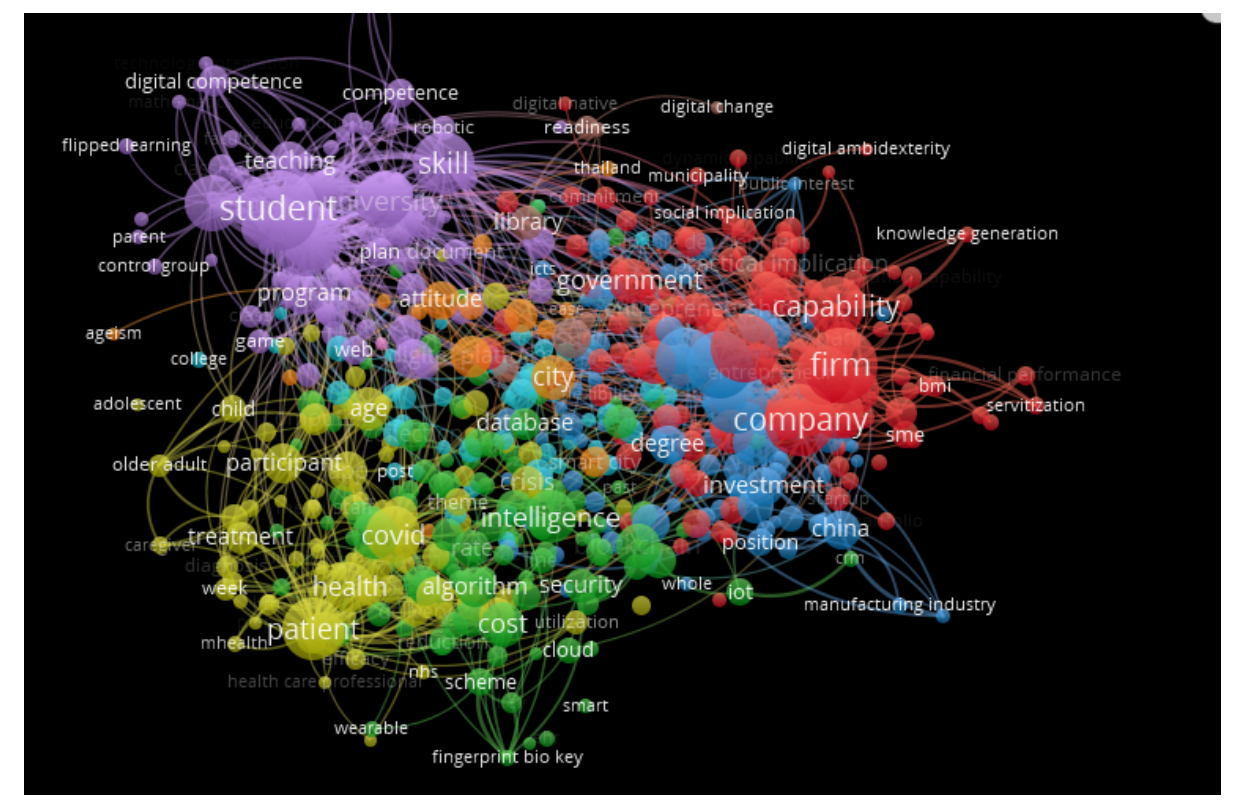

Fig. 9. Bibliometric analysis of keywords "digital innovation during Covid19 pandemic, (Scopus database, accessed 12.2020) 
During a pandemic, digital innovation has significant effects on social changes. Although professors and students work from home through digital education, however, with much challenges in "movement control order" by lockdown policies applied worldwide to the prevented epidemic outbreak, there is an arising digital innovation product to assist social people in safe by healthcare and overcome the difficult situation [42]. At the same time, in universities, digital innovation is leveraging the potential of collaboration and collective intelligence to design and launch more robust and sustainable entrepreneurial initiatives. In training, digital innovation links with the digital entrepreneurial ecosystem by highlighting the integrated digital-output and digital-environment perspectives. The reviews show that most studies mentioned that digital education connects digital innovation and digital transtion to the social, economic system, such as business, healthcare, medicine industry, and engineering, for the check figure 9.
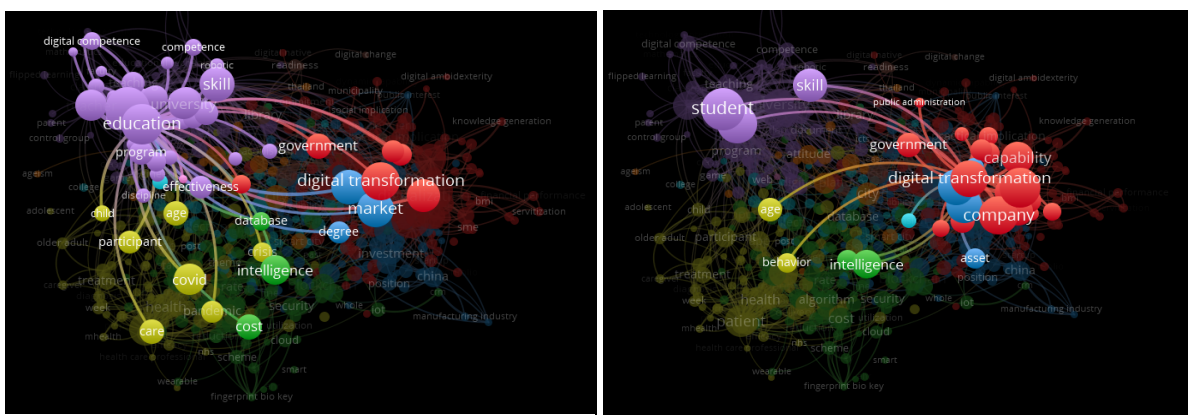

Fig. 10.Bibliometric analysis of digital education and digital innovation in socioeconomic.

Digital transformation in the education sector has implied the involvement of sustainable management to adapt to the changes imposed by new technologies [43]. First of all, when digital finance has been popularly applied in economic systems worldwide, [44] - many apps designed using in the smartphone in digital servitization innovation conveniently and effectively during a pandemic. Next is a market mechanism for achieving sustainable industrial development. Digital innovation is significantly related to sustainable industrial development, and technological innovation partially mediates the relationship between flexible environmental policy and sustainable industrial development [45]. Next digital engineering with diversity develops products, such as robotics, nanotechnology, synthetic protein, cellular agriculture, gene-editing technology, artificial intelligence, blockchain, and machine learning that affect several fields such as agriculture, industry, and hospitals [46]. This result leads to higher education students' development of interpersonal competencies when using Information and Communication Technologies for digital innovational learning and outcomes [47]. Digital strategy alongside resource finance emerges as the most effective solutions for digital innovation development in universities, industry, and the employment market. Figure 10 is showing the details of bibliometric analysis of digital education and digital innovation in socioeconomic 


\section{Conclusion}

Digital education has remarkable effects on several fields in social-economic in the worldwide during a pandemic. We utilize bibliometric analysis methods for more than 2000 articles in Scopus databse related to digital education in the year 2020 when the coronavirus outbreak worldwide. The finding shows that reviews classified 04 main clusters to analyze and discuss. These are 1) Digital Education Quick Shift Online Teaching and Learning for during Covid19 Pandemic 2) Digital Education during Pandemic and Rethinking for Sustainable Community; 3) Digital education for medical education and healthcare in hospital; 4) Digital Education and Digital innovation development during Covid19 pandemic. These findings are expected to benefit stakeholders studying and working relevant in digital education during and resilient postCovid-19 pandemic.

\section{$6 \quad$ References}

[1] N. Donthu and A. Gustafsson, "Effects of COVID-19 on business and research," Journal of Business Research, vol. 117. pp. 284-289, 2020, https://doi.org/10.1016/j.jbusres. $\underline{2020.06 .008}$

[2] Q. Wodon, "COVID-19 Crisis, Impacts on Catholic Schools, and Potential Responses | Part II: Developing Countries with Focus on Sub-Saharan Africa," COVID-19 Cathol. Sch., May 2020.

[3] C. P. Friedman et al., "Toward a science of learning systems: A research agenda for the high-functioning Learning Health System," J. Am. Med. Informatics Assoc., vol. 22, no. 1, pp. 43-50, Oct. 2015. https://doi.org/10.1136/amiajnl-2014-002977

[4] A. Bozkurt et al., "A global outlook to the interruption of education due to COVID-19 Pandemic: Navigating in a time of uncertainty and crisis," Asian J. Distance Educ., vol. 15, no. 1, pp. 1-126, 2020.

[5] N. Khan and M. I. Qureshi, "A systematic literature review on online medical services in Malaysia," Int. J. online Biomed. Eng., vol. 16, no. 6, pp. 107-118, 2020. https://doi.org/ 10.3991/ijoe.v16i06.13573

[6] S. J. Daniel, "Education and the COVID-19 pandemic," Prospects, vol. 49, no. 1-2, pp. $91-$ 96, Oct. 2020, https://doi.org/10.1007/s11125-020-09464-3

[7] M. T. Firmansyah, "Analisis Tanggapan Pengguna Terhadap Konten Channel Ardheka Production Youtube Pacitan," Sep. 2020.

[8] N. Iivari, S. Sharma, and L. Ventä-Olkkonen, "Digital transformation of everyday life How COVID-19 pandemic transformed the basic education of the young generation and why information management research should care?," Int. J. Inf. Manage., vol. 55, p. 102183, Dec. 2020. https://doi.org/10.1016/j.ijinfomgt.2020.102183

[9] M. J. Sá and S. Serpa, "The covid-19 pandemic as an opportunity to foster the sustainable development of teaching in higher education," Sustain., vol. 12, no. 20, pp. 1-16, Oct. 2020. https://doi.org/10.3390/su12208525

[10] N. Johnson, G. Veletsianos, and J. Seaman, "U.S. faculty and administrators' experiences and approaches in the early weeks of the COVID-19 pandemic," Online Learn. J., vol. 24, no. 2, pp. 6-21, 2020. https://doi.org/10.24059/olj.v24i2.2285 
[11] H. Dharmarajan et al., "Transition to a virtual multidisciplinary tumor board during the COVID-19 pandemic: University of Pittsburgh experience," in Head and Neck, Jun. 2020, vol. 42, no. 6, pp. 1310-1316. https://doi.org/10.1002/hed.26195

[12] J. Hall, "Guyton and Hall textbook of medical physiology e-Book," Elsevier Heal. Sci., pp. 304-23, 2013.

[13] C. M. Toquero, "Challenges and Opportunities for Higher Education amid the COVID-19 Pandemic: The Philippine Context," Pedagog. Res., vol. 5, no. 4, p. em0063, 2020. https://doi.org/10.29333/pr/7947

[14] M. H. Rajab, A. M. Gazal, and K. Alkattan, "Challenges to Online Medical Education During the COVID-19 Pandemic," Cureus, 2020. https://doi.org/10.7759/cureus.8966

[15] J.-Y. Song, J.-G. Yun, J.-Y. Noh, H.-J. Cheong, and W.-J. Kim, "Covid-19 in South Korea - Challenges of Subclinical Manifestations," N. Engl. J. Med., vol. 382, no. 19, pp. 18581859, May 2020. https://doi.org/10.1056/NEJMc2001801

[16] Y. W. Tang, J. E. Schmitz, D. H. Persing, and C. W. Stratton, "Laboratory diagnosis of COVID-19: Current issues and challenges," Journal of Clinical Microbiology, vol. 58, no. 6. 2020. https://doi.org/10.1128/JCM.00512-20

[17] U. Ayman, A. K. Kaya, and Ü. K. Kuruç, "The impact of digital communication and pr models on the sustainability of higher education during crises $\dagger, "$ Sustain., vol. 12, no. 20, pp. 1-15, 2020. https://doi.org/10.3390/su12208295

[18] S. Kim, S. Rosenblith, Y. Chang, and S. Pollack, "Will icmt access and use support urm students' online learning in the (Post) covid-19 era?" Sustain., vol. 12, no. 20, pp. 1-14, 2020. https://doi.org/10.3390/su12208433

[19] S. S. Kishan, S. Ramakrishnan, M. I. Qureshi, and N. Khan, "Pandemic thoughts, civil infrastructure and sustainable development: Five insights from COVID-19 across travel lenses Mergers and Acquisitions View project Systematic Literature review and MetaAnalysis View project," no. May, pp. 1690-1696, 2020.

[20] C. M. Ferreira, M. J. Sá, J. G. Martins, and S. Serpa, "The COVID-19 ContagionPandemic Dyad: A View from Social Sciences," Societies, vol. 10, no. 4, p. 77, 2020. https://doi.org/10.3390/soc10040077

[21] L. Hanna, D. Barr, H. Hou, and S. McGill, "An investigation of Modern Foreign Language (MFL) teachers and their cognitions of Computer Assisted Language Learning (CALL) amid the COVID-19 health pandemic," 2020. https://doi.org/10.5121/csit.2020.101306

[22] J. Sun, H. Li, H. Fujita, B. Fu, and W. Ai, "Class-imbalanced dynamic financial distress prediction based on Adaboost-SVM ensemble combined with SMOTE and time weighting," Inf. Fusion, vol. 54, pp. 128-144, Feb. 2020. https://doi.org/10.1016/j.inffus.2019.07.006

[23] V. Shenoy, S. Mahendra, and N. Vijay, "COVID 19 Lockdown Technology Adaption, Teaching, Learning, Students Engagement and Faculty Experience," Mukt Shabd J., vol. 9, no. 4, pp. 698-702, 2020.

[24] Y. Bao, Y. Sun, S. Meng, J. Shi, and L. Lu, "2019-nCoV epidemic: address mental health care to empower society," The Lancet, vol. 395, no. 10224. Lancet Publishing Group, pp. e37-e38, Feb. 22, 2020. https://doi.org/10.1016/S0140-6736(20)30309-3

[25] R. Iyengar, "Education as the path to a sustainable recovery from COVID-19," Prospects, vol. 49, no. 1-2, pp. 77-80, Oct. 2020. https://doi.org/10.1007/s11125-020-09488-9

[26] Y. K. Dwivedi et al., "Impact of COVID-19 pandemic on information management research and practice: Transforming education, work and life," Int. J. Inf. Manage., vol. 55, 2020. https://doi.org/10.1016/j.ijinfomgt.2020.102211 
[27] N. Iivari, S. Sharma, L. V.-O.-I. J. of Information, and undefined 2020, "Digital transformation of everyday life-How COVID-19 pandemic transformed the basic education of the young generation and why information management," Elsevier. https://doi.org/10.1016/ j.ijinfomgt.2020.102183

[28] J. Choi, M. Dutz, and Z. Usman, The Future of Work in Africa Digital Technologies for All. 2019. https://doi.org/10.1596/978-1-4648-1445-7

[29] M. Oberländer, A. Beinicke, and T. Bipp, "Digital competencies: A review of the literature and applications in the workplace," Comput. Educ., vol. 146, 2020. https://doi.org/10.10 16/j.compedu.2019.103752

[30] J. Gómez-Galán, J. Á. Martínez-López, C. Lázaro-Pérez, and J. L. S. Sánchez-Serrano, "Social networks consumption and addiction in college students during the COVID-19 pandemic: Educational approach to responsible use," Sustain., vol. 12, no. 18, 2020. https://doi.org/10.3390/su12187737

[31] A. Z. Abideen, F. B. Mohamad, and M. R. Hassan, "Mitigation strategies to fight the COVID-19 pandemic-present, future and beyond," J. Heal. Res., vol. 34, no. 6, pp. 547562, Aug. 2020. https://doi.org/10.1108/JHR-04-2020-0109

[32] A. Dzhavdatovna, K. А.-В. науки и Образования, and U. 2020, "The impact of the development of the digital economy on science and education," cyberleninka.ru.

[33] A. R. Aluisio, E. Zhu, G. Gil, T. Kenyon, V. Uzevski, and A. C. Levine, "Academichumanitarian partnerships: leveraging strengths to combat COVID-19," Glob. Health Action, vol. 13, no. 1, Dec. 2020. https://doi.org/10.1080/16549716.2020.1797296

[34] S. F. Ahmed, A. A. Quadeer, and M. R. McKay, "Preliminary identification of potential vaccine targets for the COVID-19 Coronavirus (SARS-CoV-2) Based on SARS-CoV Immunological Studies," Viruses, vol. 12, no. 3, p. 254, Feb. 2020. https://doi.org/10.3390/ v12030254

[35] M. I. Qureshi, N. Khan, S. Qayyum, S. Malik, H. S. Sanil, and T. Ramayah, "Classifications of sustainable manufacturing practices in ASEAN region: A systematic review and bibliometric analysis of the past decade of research," Sustainability (Switzerland), vol. 12, no. 21. MDPI AG, pp. 1-19, Oct. 28, 2020. https://doi.org/10.3390/su12218950

[36] M. I. Qureshi, N. Khan, S. M. Ahmad Hassan Gillani, and H. Raza, "A systematic review of past decade of mobile learning: What we learned and where to go," Int. J. Interact. Mob. Technol., vol. 14, no. 6, pp. 67-81, Apr. 2020. https://doi.org/10.3991/ijim.v14i06.13479

[37] D. Aslan and İ. Sayek, "We need to rethink on medical education for pandemic preparedness: Lessons learnt from COVID-19," Balkan Medical Journal, vol. 37, no. 4. Galenos Publishing House, pp. 178-179, 2020. https://doi.org/10.4274/balkanmedj.galenos.2020. 2020.4.002

[38] M. I. Qureshi and H. Ahmad, "A Special Section on Recent Developments in Engineering and Technologies," J. Comput. Theor. Nanosci., vol. 17, no. 2, pp. 556-557, Apr. 2020. https://doi.org/10.1166/jetn.2020.8705

[39] P.-S. Goh and J. Sandars, "A vision of the use of technology in medical education after the COVID-19 pandemic," MedEdPublish, vol. 9, no. 1, Mar. 2020. https://doi.org/10.15694/ mep.2020.000049.1

[40] N. Khan, M. I. Qureshi, I. Mustapha, A. A. Harasis, and M. Ashfaq, "The Digital Marketing Past, Present, and Future in Malaysia," J. Comput. Theor. Nanosci., vol. 17, no. 2, pp. 583-595, Apr. 2020. https://doi.org/10.1166/jetn.2020.8732

[41] N. Khan, M. I. Qureshi, H. Ahmad, and N. H. Al-Kumaim, "A Systematic Review on Emergence of Digital Marketing in ASEAN Region," J. Comput. Theor. Nanosci., vol. 17, no. 2, pp. 570-582, Apr. 2020. https://doi.org/10.1166/jctn.2020.8727 
[42] G. Elia, A. Margherita, and G. Passiante, "Digital entrepreneurship ecosystem: How digital technologies and collective intelligence are reshaping the entrepreneurial process," Technol. Forecast. Soc. Change, vol. 150, p. 119791, Jan. 2020. https://doi.org/10.1016/j.tech fore.2019.119791

[43] E. Abad-Segura, M. D. González-Zamar, J. C. Infante-Moro, and G. R. García, "Sustainable management of digital transformation in higher education: Global research trends," Sustain., vol. 12, no. 5, p. 2107, Mar. 2020. https://doi.org/10.3390/su12052107

[44] D. Sjödin, V. Parida, M. Kohtamäki, and J. Wincent, "An agile co-creation process for digital servitization: A micro-service innovation approach," J. Bus. Res., vol. 112, pp. 478491, May 2020. https://doi.org/10.1016/j.jbusres.2020.01.009

[45] "Technological forecasting and social change," Technol. Forecast. Soc. Change, vol. 34, no. 4, pp. iv-v, 1988. https://doi.org/10.1016/0040-1625(88)90012-1

[46] L. Klerkx and D. Rose, "Dealing with the game-changing technologies of Agriculture 4.0: How do we manage diversity and responsibility in food system transition pathways?," Glob. Food Sec., vol. 24, 2020. https://doi.org/10.1016/j.gfs.2019.100347

[47] E. Vázquez-Cano, M. L. Urrutia, M. E. Parra-González, and E. L. Meneses, "Analysis of interpersonal competences in the use of ICT in the Spanish university context," Sustain., vol. 12, no. 2, 2020. https://doi.org/10.3390/su12020476

\section{Authors}

Ishamuddin Mustapha is affiliated with Malaysian Institute of Industrial Technology (MITEC), Universiti Kuala Lumpur, Malaysia.

Nguyen Thuy Van is affiliated with Faculty of Social Sciences and Humanities, Universiti Teknologi Malaysia.

Masoumeh Shahverdi is affiliated with Guest lecturer at university Stavanger, Kjell Arholms gate 41, 4021 Stavanger, Norway.

Muhammad Imran Qureshi is affiliated with Faculty of Technology Management and Technopreneurship, Universiti Teknikal Malaysia Melaka, Malaysia.

Nohman Khan is affiliated with UniKL Business School, Universiti Kuala Lumpur, Malaysia.

Article submitted 2020-12-09. Resubmitted 2021-01-27. Final acceptance 2021-01-28. Final version published as submitted by the authors. 